\title{
Preparation and Characterization of Conductive Plastics Using Cassava Peel Waste and Addition of $\mathrm{CuSO}_{4}$
}

\author{
Syahrul Humaidi ${ }^{1^{*}}$, Tua Raja Simbolon ${ }^{2}$ and Muliyati $^{3}$ \\ ${ }^{1,2,3}$ Department of Physics, Faculty of Mathematics and Natural Science, Universitas Sumatera Utara \\ 20155, Indonesia
}

\begin{abstract}
This study investigated the characteristics of a conductive plastic based on root starch and $\mathrm{CuSO}_{4}$ filler. The mixture variation was $(95: 5) \% ;(90: 10) \% ;(85: 15) \% ;(80: 20) \%$ and $(75: 25) \%$. Glycerol is used to change the material as desired (plasticizer) which is called a plasticizer. The method used in the manufacture of this material is melt intercalation. Mechanical testing includes tensile strength (tensile strength) and elongation at break. Thermal testing was done using DTA (Differential Thermal Analysis) and material conductivity testing. The characterization results showed that the optimum starch composition: $\mathrm{CuSO}_{4}(75: 25) \%$ had a conductivity value of $7.3 \times 10^{-2} \mathrm{~S} . \mathrm{m}^{-1}$, a thermal test value of $410^{\circ} \mathrm{C}$. The optimum tensile strength value occurs in the composition (80:20)\% with a value of $4.606 \mathrm{MPa}$.
\end{abstract}

Keyword: conductive plastics, cassava peel, melt intercalation, DTA.

Received 03 January 2020 | Revised [31 January 2020] | Accepted [14 February 2020]

\section{Introduction}

Almost all aspects of human life are affected by the use of semiconductor materials in electronic products. The need for electronic semiconductor materials can be met from plastic composites with the active ingredient silica, considering that the materials that have been used so far come from petroleum derivatives whose availability is increasingly depleted and cannot be renewed which can cause pollution on this earth. In recent years there have been a number of important advances in the world of polymer science, including; plastics designed as a metal substitute, biodegradable polymers, polymers for medical applications, and conductive polymers, namely polymers that exhibit electrical conductivity comparable to metal conductivity [1-3].

Polymer synthesis through polymerization reactions aims to create new polymers with a specific chain structure so as to produce polymeric materials with desired mechanical characteristics and properties. Furthermore, the polymer molecules formed can be modified into new polymers by

\footnotetext{
*Corresponding author at: Jalan Biolteknologi no.1 Medan, 20155, Indonesia

E-mail address: syahrul1@usu.ac.id
} 
Journal of Technomaterial Physics Vol. 2, No. 1, 2020 / $34-41$

reaction with other polymers or low molecular weight additive compounds [4-5]. The newly developed mechanical characteristics and properties are how to change polymers that are insulators are a good conductor of electricity which in this case is called a conductive polymer.

The working principle of a conductive polymer is due to the presence of a conjugated double bond in a polymer chain. So that carbon atoms bind other carbon atoms with single and double bonds alternately which can affect the conductive properties of the conjugated polymer. The addition of a chemical compound in the form of doping will change the electron density in the $\pi$ or $\pi^{*}$ bonded polymer so that there is a change in the conductivity of the polymer from semiconductive to conductive [6-8].

Conductive plastic films that are also natural or called biodegradable are polymeric materials that change into low molecular weight compounds where at least one step in the process of degradation is through the natural metabolism of organisms. Biodegradable plastics are usually made by combining plastic with materials sourced from nature. One of the natural ingredients that can be used as a material for biodegradable plastic is starch [9-10].

The starch used in this study was starch from cassava peel waste, this starch was used as a matrix. The characteristics that will be obtained from this material are increased mechanical properties, thermal stability and are biodegradable because this material comes from natural polymers [11-12].

The results obtained will determine the most appropriate composition to produce the material with the most optimum performance. Even this plastic film preparation uses the Melt Intercalation method which is environmentally friendly because it does not use organic solvents which can later become waste. In addition, melt intercalation is also compatible with industrial processes such as injection molding. In melt intercalation, the manufacture of bionanocomposites is carried out with the aim of strengthening the material, namely by heating and cooling the material.

\section{Methods}

Making a conductive plastic material is by mixing the cassava peel starch into a solution of water and $\mathrm{CuSO}_{4}$ and adding glycerol as a plasticizer. Mixing using a stirrer on a hot plate with a temperature maintained at $80^{\circ} \mathrm{C}-90^{\circ} \mathrm{C}$ for 30 minutes until the solution thickens. This mixing is called the melt intercalation technique. Then it is poured into a mold and dried in an oven at a temperature of $45^{\circ} \mathrm{C}-50^{\circ} \mathrm{C}$ for 48 hours. This experiment was repeated with the composition variations given in Table 1. 
Table 1. The percentage of cassava mass and $\mathrm{CuSO}_{4}$

\begin{tabular}{ccc}
\hline $\begin{array}{c}\text { Sample } \\
\text { Labels }\end{array}$ & $\begin{array}{c}\text { Cassava Mass } \\
(\% \text { mass })\end{array}$ & $\begin{array}{c}\mathrm{CuSO}_{4} \\
(\% \text { mass })\end{array}$ \\
\hline 1 & 95 & 5 \\
2 & 90 & 10 \\
3 & 85 & 15 \\
4 & 80 & 20 \\
5 & 75 & 25 \\
\hline
\end{tabular}

Starch-CuSO $\mathrm{S}_{4}$ plastic film that has been successfully made using the Melt Intercalation technique is by mixing the raw materials: starch and $\mathrm{CuSO}_{4}$ at a predetermined temperature of $80-90^{\circ} \mathrm{C}$. Variations in the composition of starch powder and $\mathrm{CuSO}_{4}$ were made with the ratio: (95:5)\%; (90:10)\%; (85:15)\%; (80:20)\% and $(75: 25) \%$ with a total mass of 6 grams. Characterization carried out on the $\mathrm{CuSO}_{4}$-starch plastic film material aims to see how the interactions between the materials in forming the starch and $\mathrm{CuSO}_{4}$ plastic films on physical properties, namely density, mechanical properties: tensile strength, electrical properties: electrical conductivity and thermal properties of a material.

\section{Result and Discussion}

\subsection{Density}

Figure 1 illustrates the relationship between density and starch-CuSO${ }_{4}$ composition with the highest density value, which is found in the composition variation of $75 \%: 25 \%$ while the lowest density is at the variation in composition of 90\%:10\%. In theory, starch has a density of 1.5 $\mathrm{g} / \mathrm{cm}^{3}$ and $\mathrm{CuSO}_{4}$ has a density of $3.605 \mathrm{~g} / \mathrm{cm}^{3}$ based on the law of mixing (Rule of Mixture) at a variation of composition of $75 \%: 25 \%$ of $1.756401 \mathrm{~g} / \mathrm{cm}^{3}$ and for variations in composition of 90\%:10\% amounted to $1.470109 \mathrm{~g} / \mathrm{cm}^{3}$ where the practical density value and the theoretical density value did not have a significant difference, namely $0.022 \mathrm{~g} / \mathrm{cm}^{3}$ for the variation of 75\%:25\% and $0.229 \mathrm{~g} / \mathrm{cm}^{3}$ for the variation of $95 \%: 5 \%$. The addition of starch will cause additional pores so that the density of the material also decreases. 


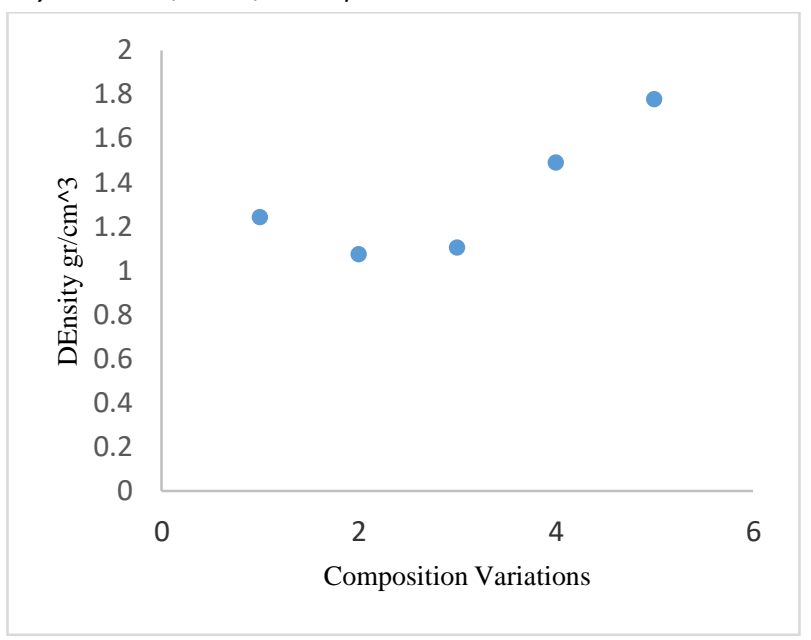

Figure 1. Graph of the Relationship between Density and Composition Variation

It can be seen from the resulting graph, the graph does not form a linear line, this is influenced by printing that is not maximal so that the resulting thickness is different for each sample and this difference in thickness affects the calculation of the material density value.

\subsection{Tensile Strength}

One of the parameters that can determine the quality of plastic film is its mechanical properties, namely the elasticity of the material. From the results of the research that has been done, the tensile strength value that can be found refer to the ASTM D638 test standard.

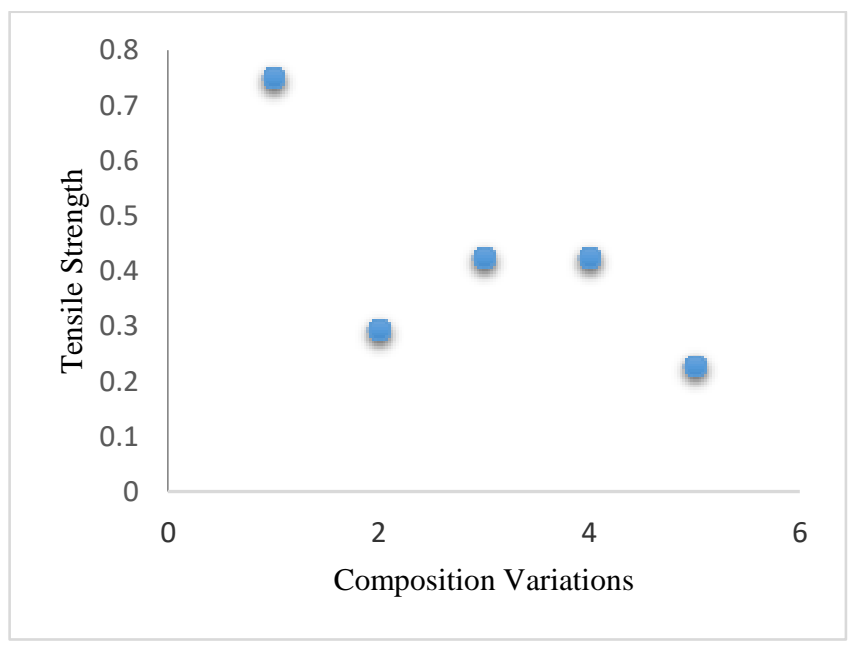

Figure 2. Graph of the relationship between Tensile Strength and Composition Variations

Figure 2 shows the tensile strength value which tends to decrease according to the decrease in starch composition or the addition of $\mathrm{CuSO}_{4}$ with the maximum value found in the variation of composition number 1 and the minimum value in variation composition number 5 , but there is a point that has decreased sharply in sample 2 this is because the mixture of both starch, glycerol and $\mathrm{CuSO}_{4}$ is not evenly distributed. Whereas Figure 3 shows the relationship between the variation in the composition of the elongation at breaking, where the maximum value is at a variation of $85 \%: 15 \%$. 


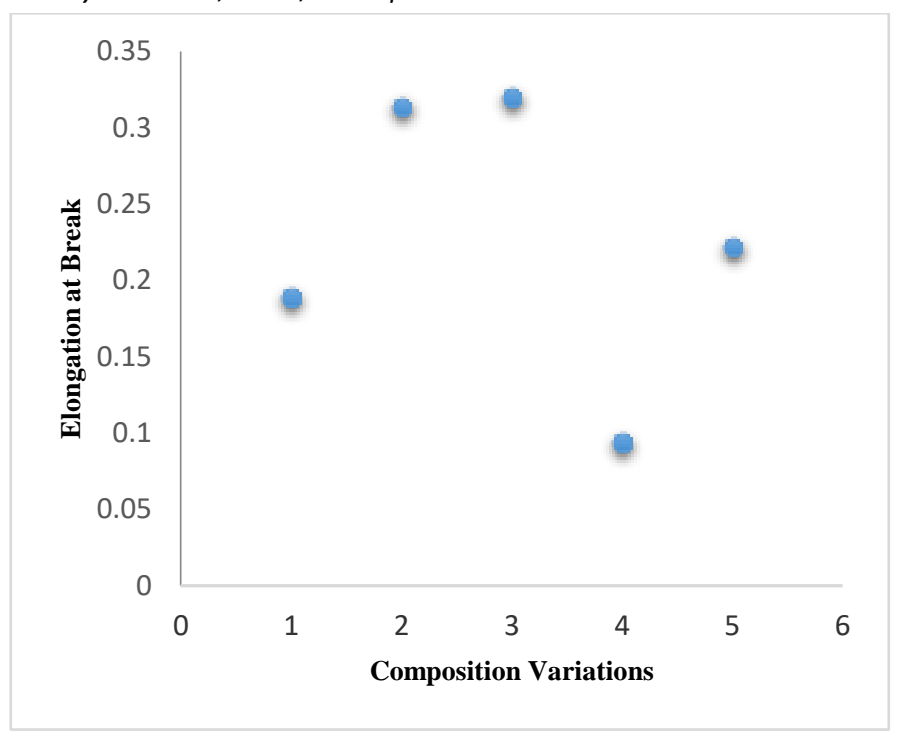

Figure 3. Graph of the relationship between Elongation at Break and Variation in Composition Figure 3 shows the elongation at break which tends to increase with the lesser amount of starch and the addition of $\mathrm{CuSO}_{4}$. This is because the addition of $\mathrm{CuSO}_{4}$ increases the proportion at breaking. This value can be said that at the end point this material breaks at that point of elasticity of the material. The final result obtained from the calculation is the modulus of elasticity of the material as illustrated below. If a straight line is drawn, the graph increases as the fill material composition is lowered.

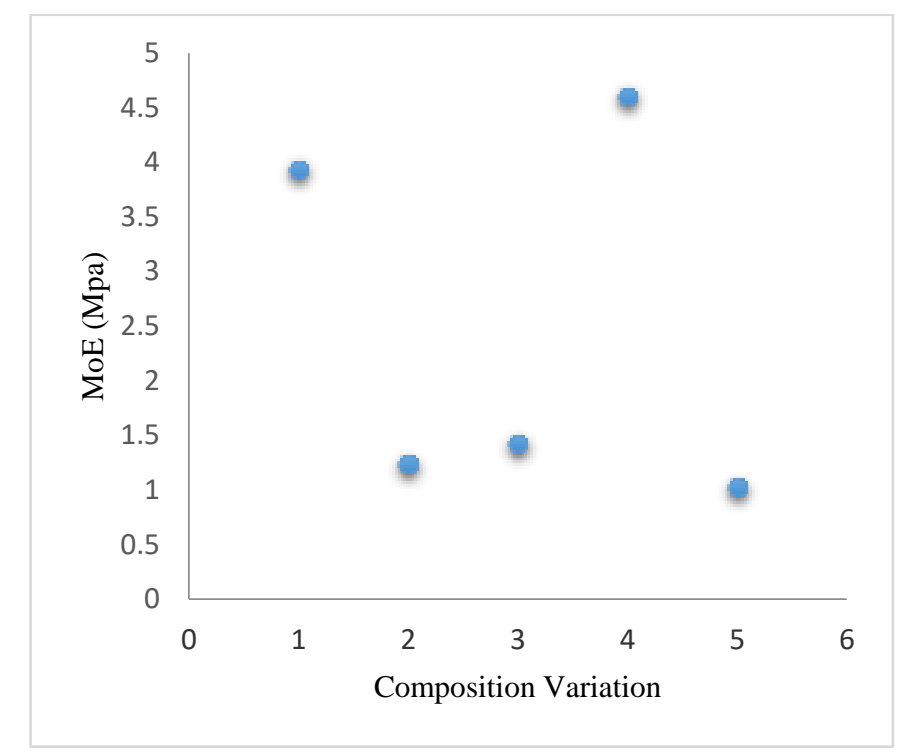

Figure 4. Graph of the relationship between $\mathrm{MoE}$ and Composition Variation

Figure 4 shows the modulus of elasticity of the material with the maximum value found in variation number 4 with a value of $4.606 \mathrm{MPa}$ and the minimum value in variation number 5 with a value of $1.033 \mathrm{MPa}$. This figure almost shows a linear state which can be seen from 3 compositions, namely samples number 2, 3 and 4, meaning that the decrease in the amount of starch and the addition of $\mathrm{CuSO}_{4}$ can increase the value of the modulus of elasticity of the material. 


\subsection{Thermal Properties}

To determine the thermal characteristics of plastic films, in this case the Differential Thermal Analyst (DTA) is used which functions to calculate the critical temperature of the material. The figure below shows the results of the DTA analysis.

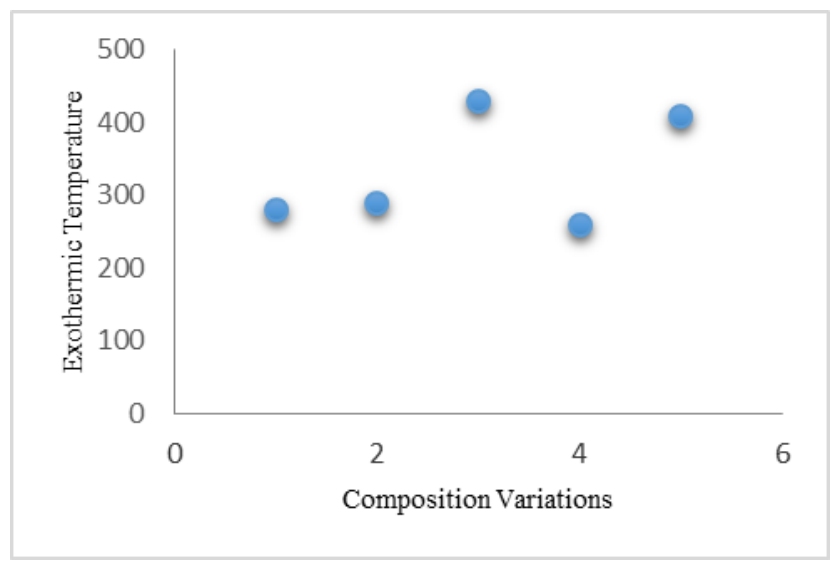

Figure 5. Relationship between Exothermic Temperature and Composition Variation

Based on Figure 5, in this composition, the DTA curve to the right with a value of $90^{\circ} \mathrm{C}$ shows the material is experiencing an endothermic reaction, namely the material receives heat from the thermocouple so that the bonds contained in the material are broken. In an endothermic reaction, the energy for breaking down the reactant bonds is higher than the total energy for the formation of the product bonds. Therefore, the enthalpy change is valuable positive and the reaction occurs not spontaneously and the material changes its shape from solid to molten plastic. At a temperature of $410^{\circ} \mathrm{C}$ the DTA curve turns to the left, this indicates that the material is experiencing an exothermic reaction in which the material releases heat so that the surrounding temperature becomes hot. Exothermic reactions occur spontaneously. In this state, the material has turned into ashes.

The same thing happens in the other variations of the composition, it's just different in the exothermic reaction. The greater the variety of starch, the faster the material burns, this indicates that there is less water content in this variation.

\subsection{Electrical Conductivity}

Electrical conductivity is the ability of a material to conduct electric current where the value of electrical conductivity is influenced by the density of the atomic structure of the material that makes it up, the number of electron charges and the level of purity. 


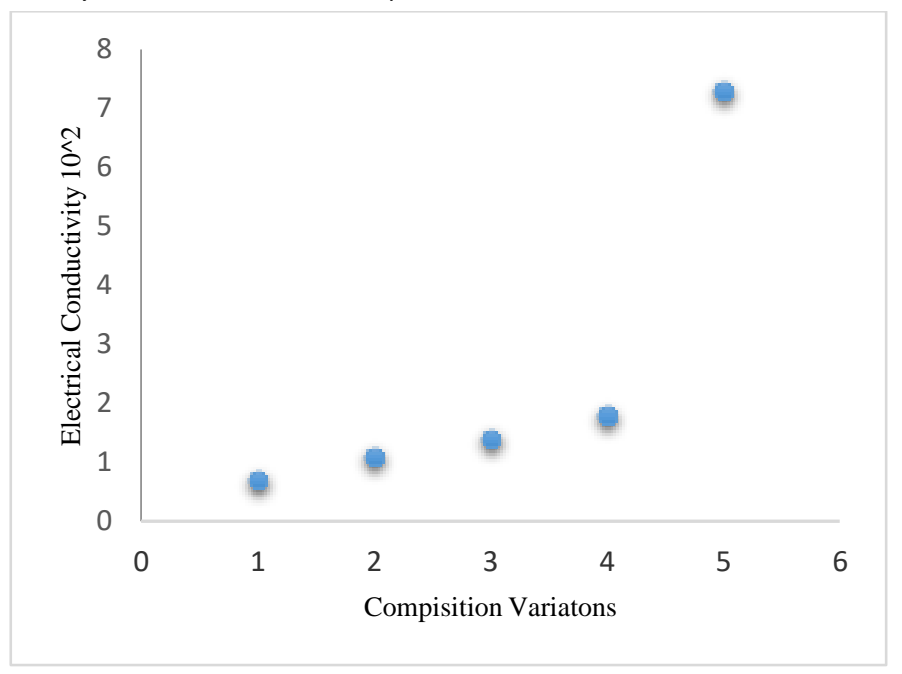

Figure 6. Relationship between Electrical Conductivity and Composition Variations

From Figure 6, it can be analyzed that the increase in the conductivity value is in line with the increasing percentage of filler composition. The optimum value obtained is at the $75 \%: 25 \%$ composition variation, while the minimum value obtained is at the $95 \%: 5 \%$ variation. The small starch composition results in more $\mathrm{Cu}$ atoms resulting in more conduction electrons. This condition can be proven by the greater the density value or density between the atoms on the plastic film in samples 1-5. Therefore, it is clear that $\mathrm{CuSO}_{4}$ has an important role in increasing the conductivity value of plastic films.

\section{Conclusion}

This material is made by the melt intercalation method, namely by mixing and then heating so that a plastic sheet is produced which can be tested for its mechanical properties. After going through the testing process this material can be said to be a semiconductor material because the

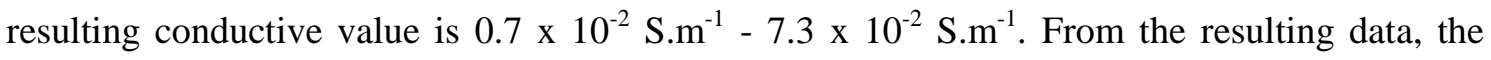
addition of $\mathrm{CuSO}_{4}$ affects the conductivity value, the more $\mathrm{CuSO}_{4}$ addition, the greater the conductivity value. While the maximum value on the mechanical properties test seen from the tensile strength of the sample is found in sample 1 (95\%:5\%) and the maximum value on thermal properties is in sample $3(85 \%: 15 \%)$.

\section{REFERENCES}

[1] T. Nezakati, A. Seifalian, A. Tan and A. M. Seifalian, "Conductive Polymers: Opportunities and Challenges in Biomedical Applications," Chemical reviews, vol. 118, no. 14, pp. 6766-6843, 2018.

[2] M. P. Stevens, Kimia Polimer, Jakarta: Pradnya Paramita, 2001.

[3] A. Khosla, "Nanoparticle-Doped Electrically-Conducting Polymers for Flexible NanoMicro Systems," The Electrochemical Society Interface, vol. 21 no.3-4, pp. 67-70, 2012.

[4] S. Laurichesse and L. Avérous, "Chemical Modification of Lignins: Towards Biobased Polymers," Progress in Polymer Science, vol. 39, no.7, pp.1266-1290, 2014. 
[5] E. Rohaeti, "Karakterisasi Biodegradasi Polimer," in Prosiding Seminar Nasional Penelitian, Pendidikan dan Penerapan MIPA: Revitalisasi MIPA dan Pendidikan MIPA dalam Rangka Penguatan Kapasitas Kelembagaan dan Profesionalisme Menuju World Class University, 16 Mei 2009, Yogyakarta, A. Wijaya, et al, Eds. Yogyakarta: FMIPA UNY, 2009, pp. 248-257.

[6] R. W. Fouts Jr, A. N. S. Au, B. E. Miller and A. J. Gotcher, Conductive Polymer Compositions and Devices, U.S. Patent 4545926, 10 August, 1985.

[7] B. Sitorus, V. Suendo and F. Hidayat, "Sintesis Polimer Konduktif sebagai Bahan Baku untuk Perangkat Penyimpan Energi Listrik," ELKHA: Jurnal Teknik Elektro, vol. 3, no. 1, pp. 43-47, 2011.

[8] D. Chandler, N. H. Thein and E. F. Chu, Conductive polymer composition. U.S. Patent 5378407, 3 January, 1995.

[9] W. Gaynor and P. Peumans, Conductive films. U.S. Patent 9112166, 18 August, 2015.

[10] Nuryetti, H. Hermansyah and M. Nasikin, "Bionanokomposit: Peluang Polimer Alami sebagai Material Baru Semikonduktor," Jurnal Riset Industri, vol. 6, no.1, pp.75-85, 2012.

[11] T. D. S. Matondang, B. Wirjosentono and D. Yunus, "Pembuatan Plastik Kemasan Terbiodegradasikan dari Polipropylena Tergrafting Anhidrid Maleat dengan Bahan Pengisi Pati Sagu Kelapa Sawit," Jurnal Valensi, vol.3, no.2, pp. 110-116, 2013.

[12] A. A. S. Curvelo, A. J. F. de Carvalho and J. A. M Agnelli, "Thermoplastic StarchCellulosic Fibers Composites: Preliminary Results," Carbohydrate Polymers, vol. 45, no.2, pp.183-188, 2001. 